\title{
No-tillage and high-residue practices reduce soil water evaporation
}

\author{
by Jeffrey P. Mitchell, Purnendu N. Singh, \\ Wesley W. Wallender, Daniel S. Munk, \\ Jon F. Wroble, William R. Horwath, Philip \\ Hogan, Robert Roy and Blaine R. Hanson
}

\section{Reducing tillage and maintaining crop} residues on the soil surface could improve the water use efficiency of California crop production. In two field studies comparing no-tillage with standard tillage operations (following wheat silage harvest and before corn seeding), we estimated that 0.89 and 0.97 inches more water was retained in the no-tillage soil than in the tilled soil. In three field studies on residue coverage, we recorded that about $0.56,0.58$ and 0.42 inches more water was retained in residue-covered soil than in bare soil following 6 to 7 days of overhead sprinkler irrigation. Assuming a seasonal crop evapotranspiration demand of 30 inches, coupling no-tillage with practices preserving high residues could reduce summer soil evaporative losses by about 4 inches (13\%). However, practical factors, including the need for different equipment and management approaches, will need to be considered before adopting these practices.

Tmproving water use efficiency is an inLreasingly important goal as California agriculture confronts water shortages. Changing tillage and crop residue practices could help.

Crop residues are an inevitable feature of agriculture. Because no harvest removes all material from the field, the remaining plant matter, or residue, accumulates and is typically returned to the soil through a series of mixing and incorporating operations involving considerable tractor horsepower (Upadhyaya et al. 2001), an array of tillage implements (Mitchell et al. 2009) and cost (Hutmacher et al. 2003; Valencia et al. 2002).

Managing residues to essentially make them disappear is the norm in California.

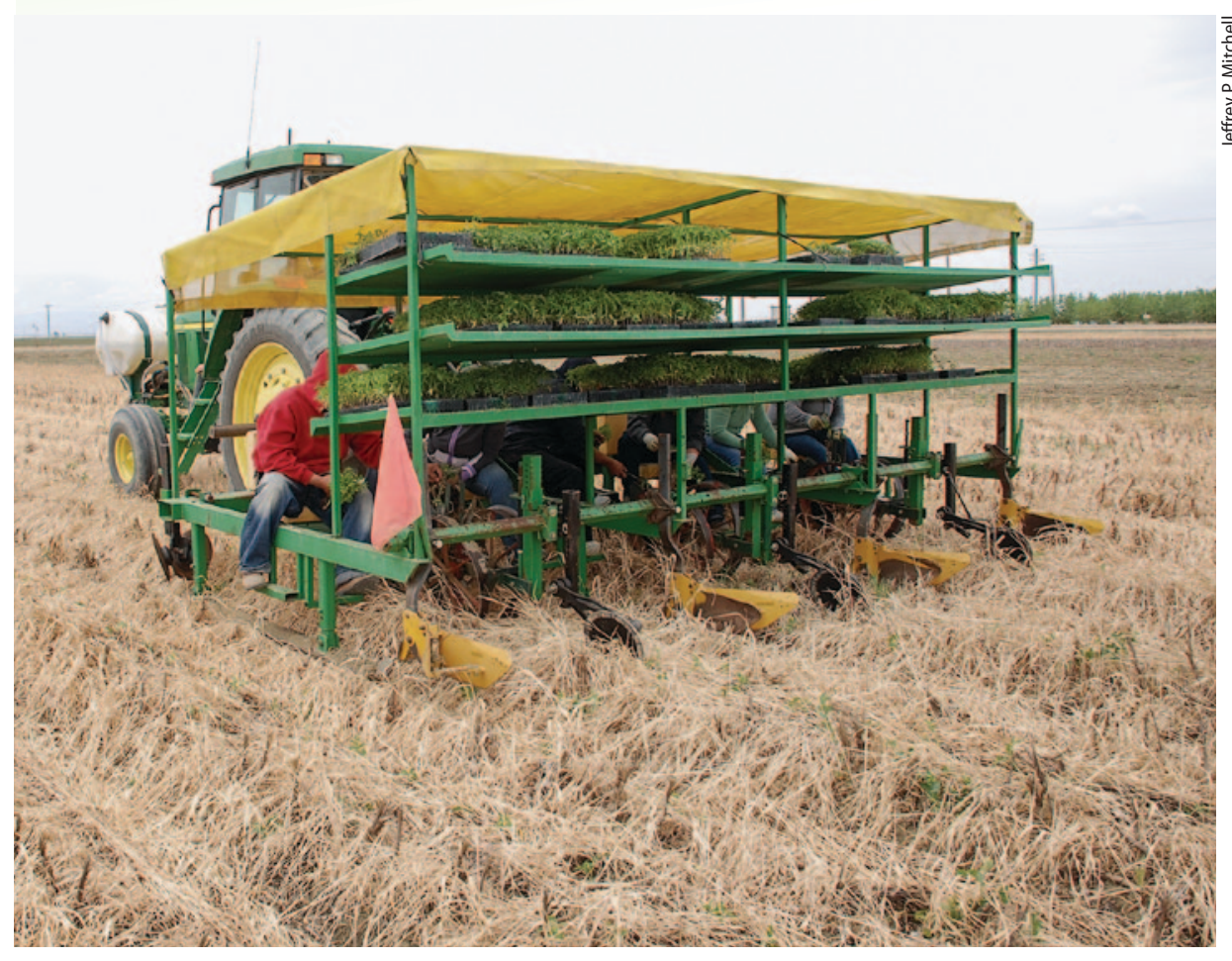

Conservation tillage allows growers to plant directly into fields that contain residue from prior crops. Above, tomatoes are transplanted into cover crop residues (triticale, rye and pea) in Five Points.

Concerns about crop pathogens are exacerbated when organic materials accumulate on the soil surface (Jackson et al. 2002), and farmers believe that they need "clean" planting beds to make the seeding and establishment of subsequent crops easier and efficient. Residue management practices in California are also influenced by tradition; until recently, they had not changed significantly for 70 years (Mitchell et al. 2009).

In regions of the world where notillage systems are common — such as Brazil, Argentina, Paraguay, Canada, Western Australia, the Dakotas and Nebraska - generating and preserving residues are an indispensable part of management and major, even primary, goals of sustainable production (Crovetto 1996, 2006). Value is derived from residues in several ways: they reduce erosion (Shelton, Jasa et al. 2000; Skidmore 1986), provide carbon and nitrogen to soil organisms (Crovetto 2006) and reduce soil water evaporation (Klocke et al. 2009; van Donk et al. 2010), along with other advantages and drawbacks (see box, page 56).

Residue amounts vary widely in cropping systems (Mitchell et al. 1999; Unger and Parker 1976). While the weight of the residues may be important, most often the percentage of soil cover or the thickness of residues is used in assessing or distinguishing their benefits (Shelton, Smith et al. 2000; USDA NRCS 2008). From research back in the Dust Bowl era, soil scientists developed relationships between the amount and architecture of residues, including crop stubble, and the reductions in soil loss due to wind (Skidmore 1986) and water (Shelton, Jasa et al. 2000). Over time, $30 \%$ or more residue cover was associated with significant reductions in soil loss, and this level of cover became an important management goal in areas where soil loss was a problem, such as the Great Plains, Pacific Northwest and southeastern United States (Hill 1996). Eventually, 30\% cover became the target linked to the definition of conservation tillage and also to the residue management technical practice standard that the U.S. Department of Agriculture's Natural

Online: http://californiaagriculture.ucanr.edu/ landingpage.cfm?article=ca.v066n02p55\&fulltext=yes DOI: 10.3733/ca.v066n02p55 
Resources Conservation Service has used for decades to evaluate conservation management plans (USDA NRCS 2008).

\section{Soil water evaporation}

Crop residues reduce the evaporation of water from soil by shading, causing a lower surface soil temperature and reducing wind effects (Klocke et al. 2009; van Donk et al. 2010). A number of studies from both irrigated and rain-fed regions around the United States where no-tillage is used have reported annual irrigation savings of as much as 4 to 5 inches (10 to 13 centimeters) (Klocke et al. 2009). Crop

\section{Glossary}

Conservation tillage: As defined by the Conservation Agriculture Systems Initiative, a wide range of production practices that deliberately reduce primary intercrop tillage operations such as plowing, disking, ripping and chiseling, and either preserve $30 \%$ or more residue cover (as in the classic Natural Resources Conservation Service definition) or reduce the total number of tillage passes by $40 \%$ or more relative to what was customarily done in 2000 (Mitchell et al. 2009).

Conventional, or traditional, tillage: The sequence of operations most commonly or historically used in a given geographic area to prepare a seedbed and produce a given crop (MPS 2000).

No-tillage, or direct-seeding: Planting system in which the soil is left undisturbed from harvest to planting, except perhaps for the injection of fertilizers. Soil disturbance occurs only at planting by coulters or seed disk openers on seeders or drills (Mitchell et al. 2009).

Residues: Plant materials remaining on land after harvesting a crop for its grain, fiber, forage and so on (Unger 2010).

Strip-tillage: Planting system in which the seed row is tilled prior to planting to allow residue removal, soil drying and warming and, in some cases, subsoiling (Mitchell et al. 2009). residues are left in the field under mechanized overhead irrigation systems. When irrigation wets the soil surface, evapotranspiration (ETc), which is the combination of transpiration and soil water evaporation, occurs. Transpiration, water moving into and through crop plants to the atmosphere, is essential for growth and crop production. Soil water evaporation, on the other hand, is generally not useful for crop production, although it does slightly cool the crop canopy microenvironment (Klocke et al. 2009).

Two processes govern soil water evaporation. When the soil is wet, evaporation is driven by radiant energy reaching the soil surface; this is called the energy-limited phase. Once the soil dries, evaporation is governed or limited more by the movement of water in the soil to the surface; this is the soil-limited phase. Subsurface drip irrigation, which typically keeps the soil surface dry, generally greatly reduces soil water evaporation (Allen et al. 1998). Irrigation systems such as furrow and overhead that frequently leave the soil surface wet can result in an evaporation loss of about $30 \%$ of total crop evapotranspiration (Klocke et al. 2009), depending on irrigation frequency.

At Kansas State University's Southwest Research and Extension Center, near Garden City, Kansas, full-surface residue coverage with corn stover and wheat stubble has been shown to reduce evaporation by $50 \%$ to $65 \%$ compared to bare soil with no shading (Klocke et al. 2009). The type of residue, though, is important, as residues from crops such as cotton and grain sorghum, which produce less material, would need to be concentrated to impractical levels to achieve evaporation decreases comparable to those obtained by typical residues from irrigated wheat (Unger and Parker 1976).

Converting to no-tillage has also been shown to reduce irrigation water needs because soil water evaporation is reduced (Pryor 2006). Conventional intercrop tillage typically involves a number of tillage passes; this is the case, for example, in the spring between winter wheat or triticale and corn seeding in San Joaquin Valley dairy silage production systems, or virtually any conventional crop rotation in which spring tillage is performed (Mitchell et al. 2009). Research in Nebraska has shown that these tillage operations dry the soil before planting to the depth of the tillage layer and that typically 0.3 to 0.75 inch ( 0.8 to 1.9 centimeters) of soil moisture may be lost per tillage pass (Pryor 2006). In Nebraska, switching from conventional tillage to no-tillage under center-pivot irrigation has been shown to save 3 to 5 inches ( 8 to 13 centimeters) of water annually, with an added savings of $\$ 20$ to $\$ 35$ per acre from pump costs (Pryor 2006). Water savings of 8 inches (20.3 centimeters) annually have been documented when conventional tillage under furrow irrigation was converted to no-tillage under overhead irrigation.

The water conservation value of crop residues and conservation tillage (Mitchell et al. 2009) has not been evaluated in the warm, Mediterranean climate of California. The objective of our study was to determine the effects of residues and no-tillage on soil water evaporation in California conditions.

\section{Tillage studies}

To determine the effects of intercrop tillage on soil water storage, we conducted

\section{Advantages and drawbacks of agricultural residues}

\begin{tabular}{ll} 
Advantages & Drawbacks \\
\hline Increase infiltration and storage of rainfall & Decrease surface soil temperatures \\
Reduce sealing of surface soil & $\begin{array}{l}\text { Increase some crop diseases } \\
\text { Retain more surface soil water, which can restrict } \\
\text { Reduce runoff }\end{array}$ \\
$\begin{array}{ll}\text { access to field } \\
\text { Reduce water erosion }\end{array}$ & $\begin{array}{l}\text { Create challenges for seeding and crop } \\
\text { establishment }\end{array}$ \\
Reduce soil water evaporation & \\
Provide habitat and food sources for earthworms & \\
Increase snow trapping and subsequent water & \\
storage from melted snow &
\end{tabular}


studies in 2009 and 2010 at the UC West Side Research and Extension Center in Five Points. We monitored the surface water content in a Panoche clay loam soil during the transition from wheat harvest to corn seeding under no-tillage and standard tillage. Each treatment plot consisted of fifteen 5-foot-by-300-foot beds and was replicated three times in a randomized complete block design. Following wheat silage harvest in late April of each year, the no-tillage plots were left undisturbed, while the standard tillage plots were disked twice, chiseled to an approximate depth of 1 foot and disked again before being listed to recreate 5 -foot-wide planting beds for corn.

Surface soil water content in the top 0 to 5 inches and 0 to 8 inches ( 0 to 12 and 0 to 20 centimeters) of soil was monitored during this transition between crops, using time-domain reflectrometry (TDR) (Hydrosense, Campbell Scientific, Logan, UT) instrumentation that had been calibrated for the experimental soil and gravimetric water content techniques. Water content sampling consisted of about 12 TDR readings made in the outer 6 inches of randomly selected bed tops in each plot and four to six 3-inch-diameter soil cores collected in similar areas and composited for each gravimetric water content measurement. Soil bulk density was determined at the start of each study.

To account for possible changes in soil bulk density resulting from standard tillage, two 3-inch-diameter soil cores per plot were collected, dried and weighed following the disking operations. These density determinations were then used with the gravimetric water content measurements to calculate soil volumetric water content (SVWC). Percentages of

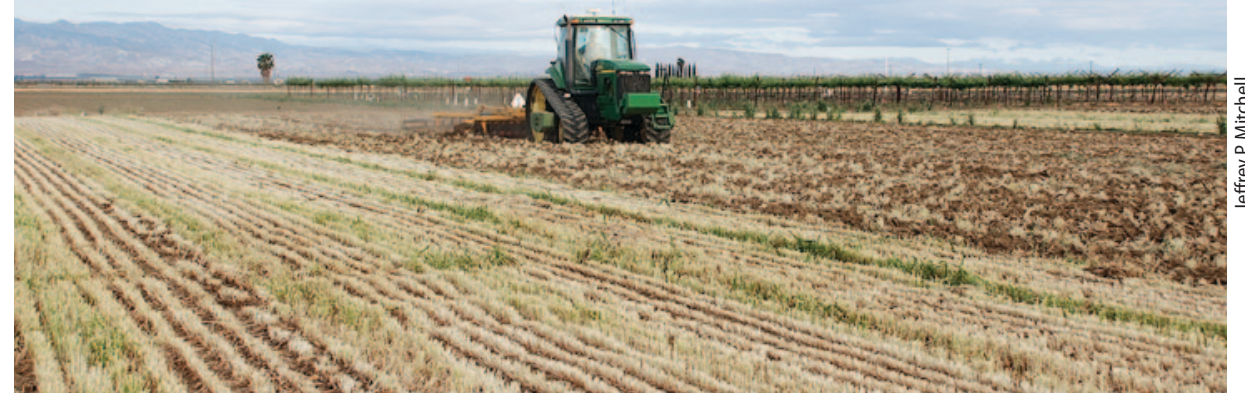

A 2-year study at the UC West Side Research and Extension Center in Five Points compared soil water content in tilled (right, subsoil ripped) and no-tillage (left) plots. wheat straw and corn stover residue cover were determined using the line-transect method (Bunter 1990).

\section{Residue studies}

The effects of wheat straw residues on soil water evaporation were determined in one study in 2009 and two studies in 2010. These studies were also conducted in a Panoche clay loam soil at the UC West Side Research and Extension Center. Before each study, the field was prepared by disking, land planing and ring rolling to create uniform and level conditions throughout. Soil in the entire experimental field had been similarly managed before each study in terms of previous cropping and tillage. Residue and baresoil treatment plots measured 65.8 by 75.1 feet and were replicated four times in a randomized complete block design.

The residue plots were established by manually placing wheat straw on them to an approximate height of 4 inches (10 centimeters); the straw was collected from a uniform crop that had been grown and chopped as for silage in the study field before the start of each study. An overhead, hose-fed, eight-span, lateral-move irrigation system (Model 6000, Valmont Irrigation, Valley, NE) fitted with Nelson (Walla Walla, WA) pressure-regulated
TABLE 1. Soil volumetric water content at depths of $0-5$ and $0-8$ inches in conventional tillage plots (before and after tillage) and no-tillage plots, 2009 and 2010

\begin{tabular}{|c|c|c|c|c|}
\hline \multirow[b]{2}{*}{ Tillage system } & \multicolumn{2}{|c|}{2009} & \multicolumn{2}{|c|}{2010} \\
\hline & Before & After & Before & After \\
\hline & n...... & $\ldots \ldots \ldots$ & n..... & $\ldots \ldots \ldots$ \\
\hline \multicolumn{5}{|l|}{$0-5$ in $(0-12 \mathrm{~cm})$} \\
\hline Conventional & $20.7 a^{*}$ & $12.8 \mathrm{~b}$ & $20.0 a$ & $11.9 \mathrm{~b}$ \\
\hline No-tillage & $19.9 a$ & $22.5 a$ & $20.9 a$ & $20.2 a$ \\
\hline \multicolumn{5}{|l|}{$0-8$ in $(0-20 \mathrm{~cm})$} \\
\hline Conventional & & & $23.5 a$ & $13.7 \mathrm{~b}$ \\
\hline No-tillage & & & $21.7 a$ & $23.4 a$ \\
\hline
\end{tabular}

* Values are means of four replications. Means within a column followed by the same letter are not significantly different at $P=0.05$ according to Fisher's Protected LSD. nozzles at 48 inches above the soil surface and 5-foot spacing was used to apply 2.5 inches (6.4 centimeters) of water to each plot in the 2009 study and 1.2 inches (3.0 centimeters) to each plot in the 2010 studies. This system's nozzle and hose configurations provided Christensen application uniformities (CUs) of 93\%.

Surface soil water content (in the top 0 to 5 and 0 to 8 inches of soil) was monitored daily, using TDR and gravimetric water content techniques. In 2009, monitoring was done for 14 days before irrigation and 7 days after, and in 2010, monitoring was done only for 7 days after. Each daily sampling consisted of about 15 TDR readings collected along both sides of two transects in each plot and four soil cores 4 inches (10 centimeters) in diameter taken in similar areas of each plot and composited for gravimetric water content measurements. Soil bulk density measurements were made for each study using the compliant cavity method (USDA NRCS 1996).

Aboveground air temperatures (1 meter above the soil surface) and soil temperatures at $0.4,3.4$ and 7.9 inches (1, 10 and 20 centimeters) below the soil surface were determined every $15 \mathrm{~min}$ utes during the second study in 2010, using HOBO Pro v2 data-logging sensors (Spectrum Technologies, IL). Percentage canopy cover was determined by placing a LI-191 Line Quantum Sensor (LI-COR, Logan, UT) in full sun and then below the residue at six locations in each residue plot and calculating the amount of photosynthetically active radiation that had been intercepted by the residue.

\section{Less evaporation with no-tillage}

In both years, the five tillage passes performed in the conventional plots over about 5 days after wheat chopping and before corn seeding - reduced the SVWC in the soil's top 5 inches (13 centimeters) (table 1). The reduction was $7.9 \%$ 
in 2009 and $8.1 \%$ in 2010; the SVWC in the no-tillage plots remained unchanged. When the SVWC was recorded in the top 8 inches of the soil in 2010, we found it was reduced by $9.8 \%$, or 0.77 inch, in the tilled plots. Extrapolating the reduction in the top 5 inches to a 1-foot depth, which more closely matches the actual depth of

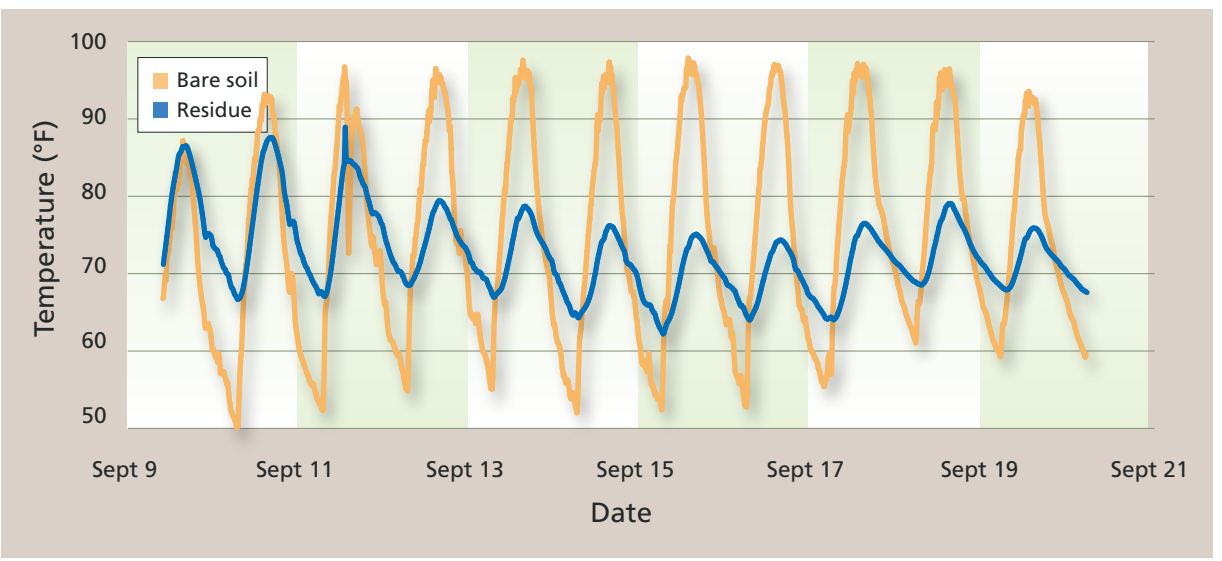

Fig. 1. Maximum soil temperature $\left({ }^{\circ} \mathrm{F}\right)$ at 1 centimeter below soil in bare-soil and residue-covered plots, 2010 evaporation study.

\begin{tabular}{|c|c|c|c|}
\hline \multicolumn{4}{|c|}{$\begin{array}{l}\text { TABLE 2. Soil volumetric water content in bare-soil and residue treatments } \\
\qquad \text { at depths of } 0-5 \text { and } 0-8 \text { inches, } 2009\end{array}$} \\
\hline & Sept. 4 & Sept. 10 & Sept. 18 \\
\hline & ......... & $\cdots \% \cdots$ & ..... \\
\hline \multicolumn{4}{|c|}{$0-5$ in $(0-12 \mathrm{~cm})$} \\
\hline Bare soil & $45.0 b^{*}$ & $23.4 b$ & $16.7 b$ \\
\hline Residue & $48.2 \mathrm{a}$ & $37.2 \mathrm{a}$ & $34.4 a$ \\
\hline \multicolumn{4}{|c|}{$0-8$ in $(0-20 \mathrm{~cm})$} \\
\hline Bare soil & $43.6 a$ & $26.7 b$ & $21.6 \mathrm{~b}$ \\
\hline Residue & $45.6 a$ & $35.8 a$ & $33.4 \mathrm{a}$ \\
\hline
\end{tabular}

\begin{tabular}{|c|c|c|c|}
\hline \multicolumn{4}{|c|}{$\begin{array}{l}\text { TABLE 3. Soil volumetric water content in bare-soil and residue treatments } \\
\text { at depths of } 0-5 \text { and } 0-8 \text { inches, first and second } 2010 \text { studies }\end{array}$} \\
\hline & Aug. 3 & Aug. 4 & Aug. 10 \\
\hline & n...... & $\ldots \% \%$ & n....... \\
\hline \multicolumn{4}{|c|}{$0-5$ in $(0-12 \mathrm{~cm})$} \\
\hline Bare soil & $7.0 a^{*}$ & $34.4 a$ & $15.2 b$ \\
\hline Residue & $8.3 a$ & $35.3 a$ & $24.4 a$ \\
\hline \multicolumn{4}{|c|}{$0-8$ in $(0-20 \mathrm{~cm})$} \\
\hline Bare soil & $7.1 \mathrm{a}$ & $29.8 a$ & $15.6 b$ \\
\hline \multirow[t]{3}{*}{ Residue } & $7.9 a$ & $29.6 a$ & $27.7 a$ \\
\hline & Sept. 9 & Sept. 11 & Sept. 18 \\
\hline & $\ldots \ldots \ldots$ & $\ldots \ldots \ldots$ & $\ldots \ldots \ldots$ \\
\hline \multicolumn{4}{|c|}{$0-5$ in $(0-12 \mathrm{~cm})$} \\
\hline Bare soil & $7.7 \mathrm{a}$ & $42.5 \mathrm{a}$ & $22.0 \mathrm{~b}$ \\
\hline Residue & $8.7 a$ & $43.2 \mathrm{a}$ & $30.0 \mathrm{a}$ \\
\hline \multicolumn{4}{|c|}{$0-8$ in $(0-20 \mathrm{~cm})$} \\
\hline Bare soil & $8.6 a$ & $37.7 \mathrm{~b}$ & $19.2 b$ \\
\hline Residue & $8.1 \mathrm{a}$ & $32.4 a$ & $22.9 a$ \\
\hline
\end{tabular}

tillage, suggests that the soil water losses from tillage might have been 0.93 inch ( 2.4 centimeters) in 2009 and 0.96 inch $(2.4$ centimeters) in 2010.

In 2009 and 2010, the percentage residue cover $(75 \%$ and $95 \%$, respectively) in the no-tillage plots was many times higher than in the tilled plots $(7.5 \%$ and $6.0 \%$, respectively). Although no-tillage management eventually will improve the soil's water-holding characteristics, our studies had not been in place long enough to produce such a change. It is likely that the differences in SVWC between the tilled and no-tillage plots resulted from increased soil-water evaporation in the tilled plots relative to the no-tillage plots.

\section{Impact of residues}

In the residue studies, we applied wheat straw residue to a depth of about 4 inches (10 centimeters), which is comparable to application rates in other residue studies (Klocke et al. 2009; Unger and Parker 1976) and to levels of residue accumulation recently measured in sustained tomato and cotton conservation-tillage systems at the same research site and also in related corn and tomato conservationtillage studies on the UC Davis campus (Mitchell et al. 2005). The soil coverage was over $95 \%$ in each of the three studies.

Residues reduced near-surface daily maximum soil temperatures, measured under the residues at 0.4 inch ( 1 centimeter) below the soil surface, by up to $20^{\circ} \mathrm{F}$ relative to bare-soil conditions during the second 2010 study (fig. 1). At the end of each of the three studies, our recordings showed that more water was retained in the soil under the residues than in the bare-soil plots (tables 2 and 3). The amount of retained water in the soil at the end of the studies could have been affected by evaporation losses, initial SVWC and percolation losses. Numerical simulation of water flow in the control volume using HYDRUS 1-D software and data from the 2010 studies - indicated that the effect of percolation losses on the difference in evaporation losses between the residue and bare-soil plots was negligible (Singh et al. 2011).

Differences in SVWC between the bare-soil and residue plots at the shallow depth (top 5 inches) were greatest in the 2009 study, when 0.83 inch (2.1 centimeters) more water was retained in the residue than in the bare-soil plots. In the first 
2010 study, the difference was 0.43 inch (1.1 centimeter) and in the second 2010 trial, 0.38 inch ( 0.97 centimeter) (data not shown). A portion of this difference in SVWC between residue and bare-soil crops was caused by the different initial SVWC in the plots. Accounting for the initial SVWC, the change in SVWC due to evaporation was 0.68 inch (1.7 centimeters) in 2009, 0.37 inch ( 0.9 centimeter) in the first 2010 study and 0.33 inch ( 0.8 centimeter) in the second 2010 study. The particularly high number for the 2009 study was a result of the longer evaporation estimation period -2 weeks rather than 7 to 8 days as in the other two studies; the change in SVWC for 1 week during the 2009 study was 0.50 inch (1.3 centimeters). The changes in SVWC between treatments at the greater depth (top 8 inches) ranged from 0.33 inch (0.8 centimeter) to 0.89 inch ( 2.3 centimeters) when differences in initial SVWC were accounted for.

As shown in other studies, the evaporation rate from bare soil after initial wetting is greater than from soil under residues. Residues shield the soil surface from solar radiation. Likewise, air movement at the soil surface is reduced under residues, resulting in a lower evaporation rate (van Donk et al. 2010). However, if the soil under residues is not rewetted by irrigation or rainfall, evaporation will continue and after many days can exceed that from bare soil.

In our studies, about 0.06 to 0.08 inch ( 0.15 to 0.2 centimeter) of the initial applied water was retained in the residue itself (fig. 2). This water, however, almost completely evaporated within about 2 days. These recordings match quite

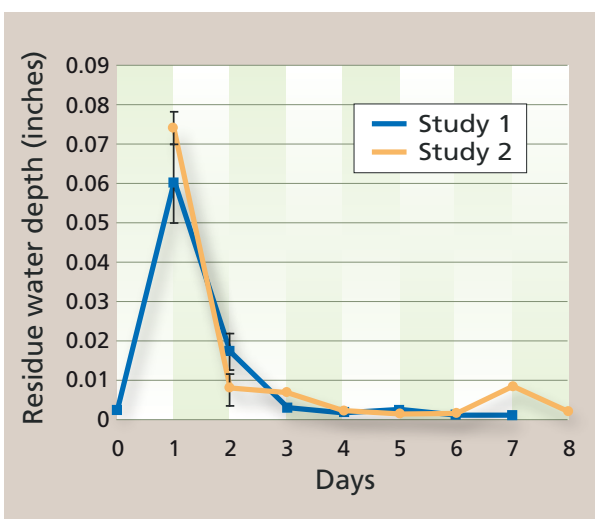

Fig. 2. Amount of water in residue during 2010 evaporation studies.

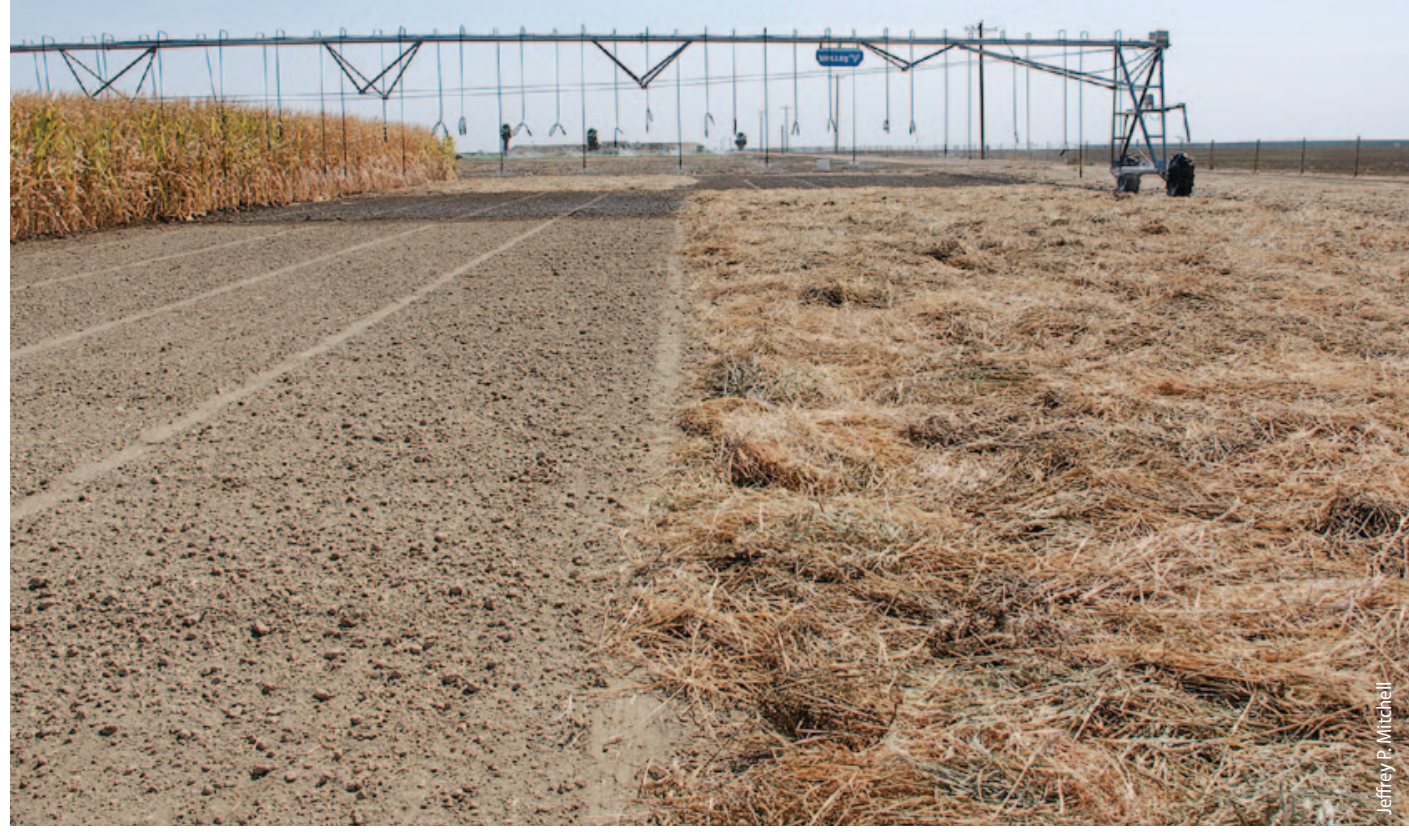

The water evaporation rate from plots with residue (example at right) was consistently lower than from bare-soil plots (left) after overhead irrigation, in Five Points.

closely the results of studies in Nebraska, where 0.08 to 0.1 inch $(0.2$ to 0.3 centimeter) of water evaporated from residue after wetting events (van Donk et al. 2010). They indicate that evaporation losses from residues can be significant, particularly if irrigation or rainfall is light and frequent. Evaporation of 0.1 inch from an 0.5 -inch (1.3-centimeter) application is a $20 \%$ loss, which is significant (van Donk et al.

2010). Heavier or less-frequent irrigations would be more effective in decreasing the proportional water loss from residues; however, concerns about runoff at high application rates may limit an irrigator's option to do that. In this regard, no-tillage offers an advantage: sustained no-tillage allows higher irrigation rates before runoff, because changes in soil structure and porosity result in higher infiltration rates (Pryor 2006).

\section{Water conservation}

The general finding that residue cover tends to reduce soil water evaporation relative to bare soil has been consistently shown in a wide range of studies (Crovetto 1996; Klocke et al. 2009; Unger and Parker 1976; van Donk et al. 2010). The water conservation value of residues, however, remains controversial for a number of reasons (van Donk et al. 2010). In some U.S. regions, the harvest of residues for animal feed or as a source of cellulose for domestic biofuel production is increasing. Because maintaining residues has long been a conservation goal and a primary means for reducing erosion, research is now under way in these areas to evaluate the impacts of crop residue removal and develop recommendations for sustainable removal rates (Andrews 2006) and to better quantify both the agronomic and economic effects of residues on components of the soil water balance (van Donk et al. 2010).

Predicting or projecting the seasonlong impacts of residue cover relative to bare soil is complicated and depends on a number of interacting factors, including soil type, planting date, crop type, crop spacing, irrigation frequency and potential evapotranspiration. Work by Klocke et al. (2009) in Kansas suggested that residues may reduce energy-limited evaporation by $50 \%$ to $65 \%$ compared with evaporation from bare soil with no shading.

Our study is limited because we did not have a crop growing in the field when the measurements were taken. To compare our findings with recent similar studies that have included a transpiring crop, we estimated the longer-term impacts of having residues in a field relative to bare soil using data from our study and the following assumptions: (1) bare soil in our three studies evaporated about $84 \%$ more water than the soil with residues; and (2) for a typical summer crop 
produced in the Five Points region, evapotranspiration is about 30 inches.

We used two different data sources to estimate the longer-term water conservation potential of residue-covered versus bare soil. Data from Garden City, Kansas, indicated that evaporation was about 30\% of evapotranspiration for a center-pivotirrigated corn crop (Klocke et al. 2009). In addition, unpublished data from B. R. Hanson suggested that evaporation on furrow-irrigated tomatoes in California as a percentage of evapotranspiration is more like $15 \%$. Under these two scenarios, an $84 \%$ reduction in evaporation under residues would correspond to 2.1 inches (5.3 centimeters) more water lost from bare soil than from under residues if evaporation were $15 \%$ of evapotranspiration, and 4.1 inches (10.4 centimeters) if evaporation were $30 \%$ of evapotranspiration. This extrapolation is remarkably close to the 3.5 to 4.1 inches (9.0 to 12.4 centimeters) of water savings from leaving residues on cornfields in west-central Nebraska (van Donk et al. 2010) and the

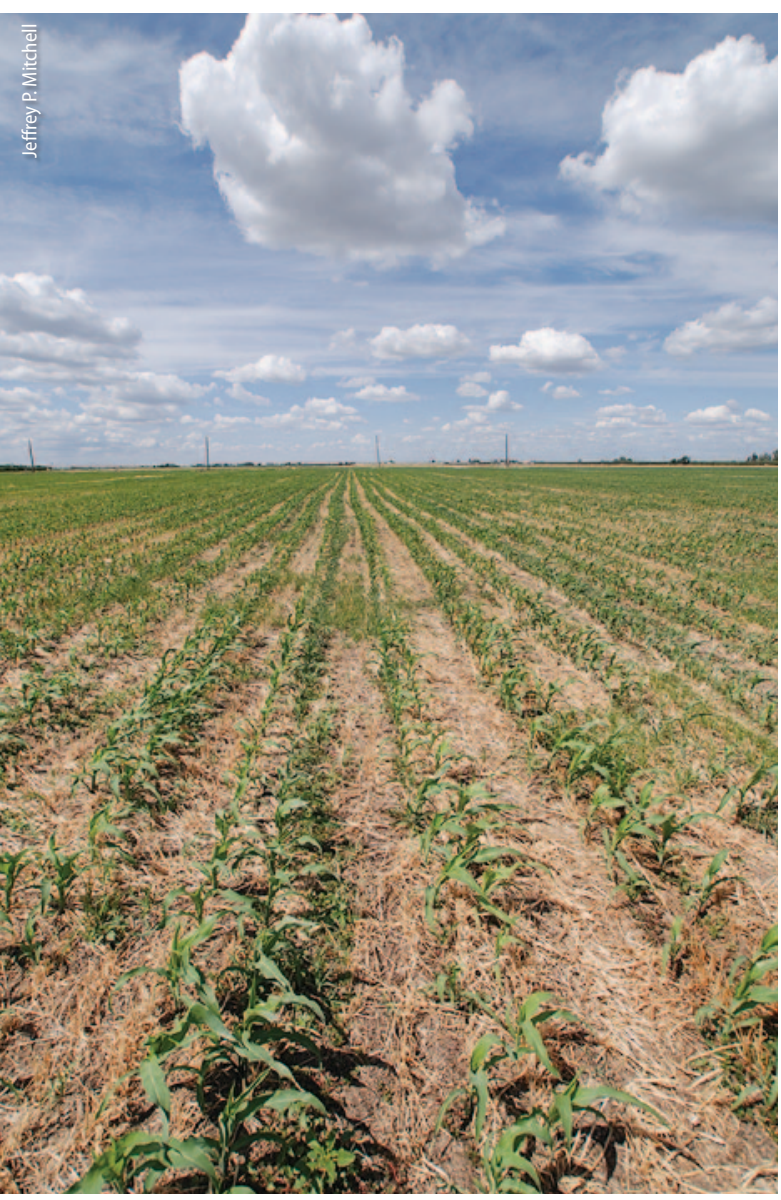

No-tillage corn grows in triticale and corn residues in Turlock.
2.9 inches (7.5 centimeters) of water savings in Nebraska on irrigated cornfields with growing-season crop residues (Klocke et al. 2009).

\section{Prospects for California}

Improving the water use efficiency of crop production by increasing the amount of water that is transpired by a crop relative to the amount that is evaporated by the soil has been identified as a management goal for California agriculture (Burt et al. 2002; Hsiao

and $\mathrm{Xu}$ 2005).

Transitioning from tillage and residue management practices used in California today to high-residue, no-tillage practices may partially accomplish this goal, according to our studies and similar recently published studies in Nebraska and Texas. In our studies, coupling notillage with high-residue preservation practices could reduce soil water evaporative losses during the summer season by about 4 inches (10.2 centimeters), or 13\%, assuming a seasonal evapotranspiration demand of 30 inches. In Texas, a study of strip-till cotton grown in wheat residues, compared to cotton under conventional tillage, showed decreased soil water evaporation, increased crop transpiration and an increase in water use efficiency of $37 \%$ (Lascano et al. 1994).
However, a number of practical factors will need to be addressed before any wholesale transformation to no-tillage, residue-preserving production can be envisioned in California; these include the relative ease with which a farm's existing cropping mix might be converted to no-till, the need for and cost of new equipment and the learning curve for new management practices. Also, more research is needed on water balance and crop productivity under no-tillage and

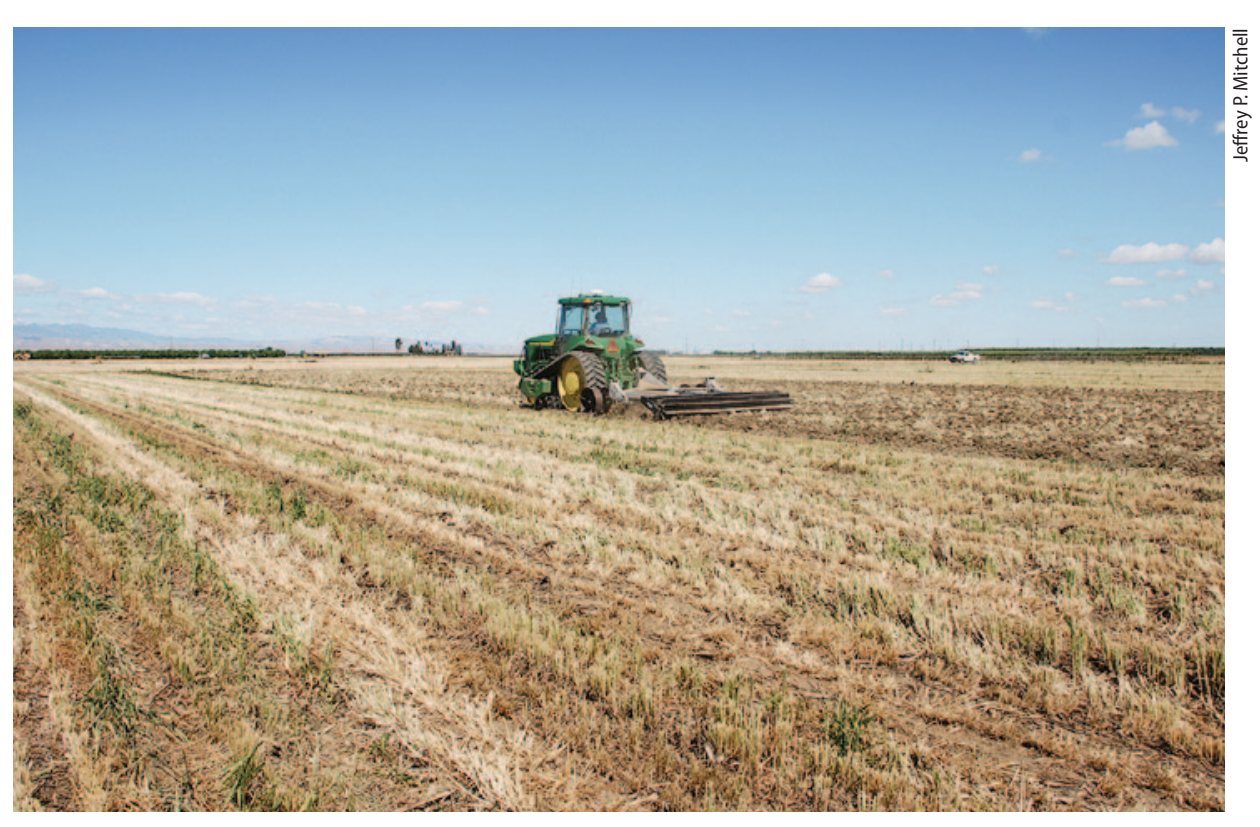

In Five Points, soil is disked to incorporate residues - the conventional practice. Transitioning to reduced-tillage practices could significantly improve water use efficiency in California agriculture. 
sustaining productivity (Mitchell et al. 2005; Mitchell et al. in press).

The use of cover crops to provide relatively high surface residue levels has also been tried commercially in tomato fields in the western San Joaquin Valley in recent years. Transitioning to such management systems, however, has required considerable planning, know-how and persistence. The reductions in soil water evaporation that have been shown here add to the list of benefits of conservationtillage systems for California producers (Mitchell et al. 2009; Mitchell et al. in press).

J.P. Mitchell is Cropping Systems Specialist, Department of Plant Sciences, UC Davis; P.N. Singh is Postdoctoral Researcher, Department of Land, Air and Water Resources, UC Davis; W.W. Wallender is Professor, Department of Land, Air and Water Resources, UC Davis; D.S. Munk is Advisor, UC Cooperative Extension, Fresno

\section{For more information:}

\section{Conservation Agriculture Systems Initiative} http://ucanr.org/CASI
County; J.F. Wroble is Field Assistant, UC Cooperative Extension, Fresno County; W.R. Horwath is Professor, Department of Land, Air and Water Resources, UC Davis; P. Hogan is District Conservationist, U.S. Department of Agriculture Natural Resources Conservation Service (USDA NRCS), Woodland; R. Roy is Resource Conservationist, USDA NRCS, Fresno; and B.R. Hanson is Irrigation Specialist (Retired), Department of Land, Air and Water Resources, UC Davis.
We gratefully acknowledge Bert Garza, Jaime Solorio, Merf Solorio, Nelson Vallejo and Tracy Waltrip for their assistance at the UC West Side Research and Extension Center in Five Points. We also are grateful to the UC Water Resources Center for a research grant that partially supported this research and to Dwayne Beck of Dakota Lakes Research Farm in Pierre, S.D., for fundamental inspiration for this work.
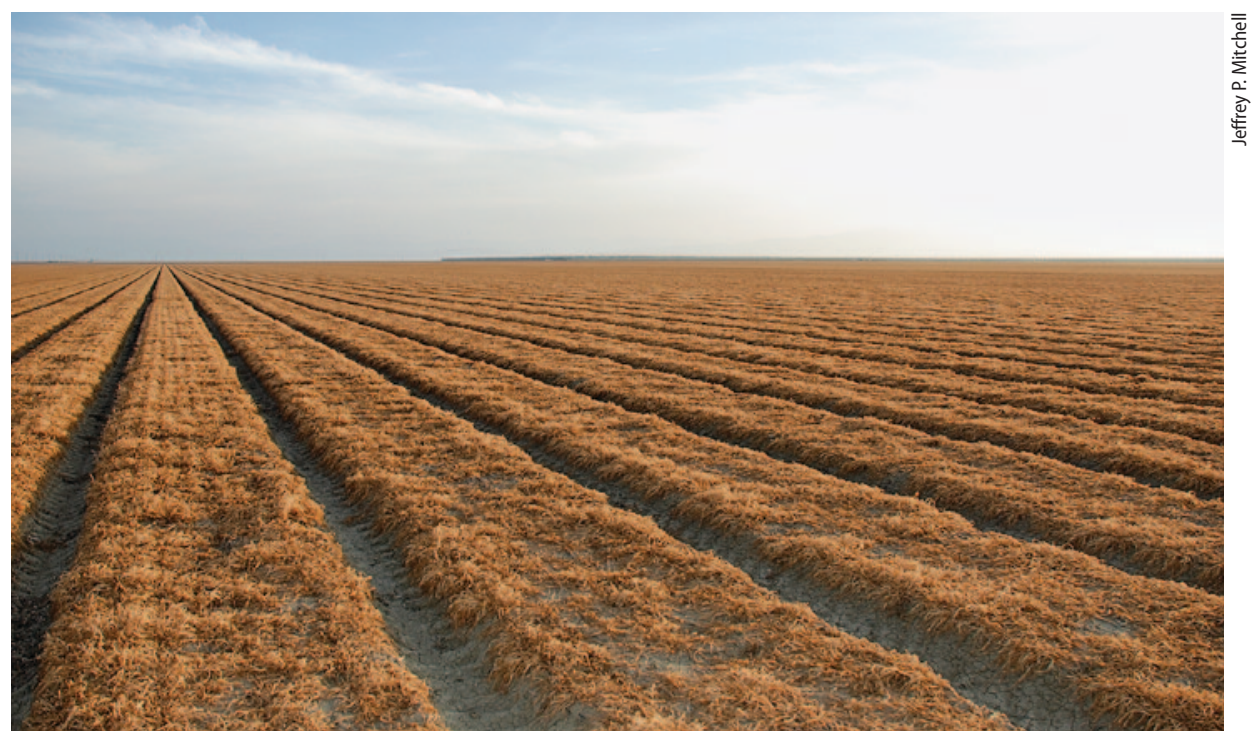

In Firebaugh, fresh-market tomatoes will be planted directly into a triticale cover crop that has been treated with herbicides.

\section{References}

Allen RG, Pereira LS, Raes D, Smith M. 1998. Crop Evapotranspiration: Guidelines for Computing Crop Water Requirements. FAO Irrigation and Drainage Paper 56 Food and Agriculture Organization of the United Nations. Rome, Italy. ISBN 92-5-104219-5.

Andrews SS. 2006. Crop Residue Removal for Biomass Energy Production: Effects on Soils and Recommendations. White Paper. USDA Soil Quality National Technology Development Team. http://soils.usda.gov/sqi/management/ files/AgForum_Residue_White_Paper.pdf.

Bunter W. 1990. The Line-Transect Method of Measuring Crop Residue Cover. USDA Soil Conservation Service Technical Notes Agronomy 50. http://efotg.nrcs.usda. gov/treemenuFS.aspx.

Burt CM, Mutziger A, Howes DJ, Solomon KH. 2002.

Evaporation from Irrigated Agricultural Land in California. Irrigation Training and Research Center Report R 02-001. California Polytechnic State University, San Luis Obispo. 478 p. www.itrc.org/reports/evapca/evapca.pdf. Crovetto C. 1996. Stubble over the Soil: The Vital Role of Plant Residue in Soil Management to Improve Soil Quality. Am Soc Agron, Madison, WI. 241 p.

Crovetto C. 2006. No Tillage: The Relationship between No Tillage, Crop Residues, Plants and Soil Nutrition. Hualpen, Chile: Trama Impresores. 216 p.

Hill PR. 1996. Conservation Tillage: A Checklist for U.S. Farmers. Conservation Technology Information Center. West Lafayette, IN. 35 p.

Hsiao T, Xu L. 2005. Evapotranspiration and relative contribution by the soil and the plant. In: California Water Plan Update 2005. Vol. 4. p 129-60.

Hutmacher RB, Vargas RN, Weir BL, et al. 2003. Sample Costs to Produce Cotton. UC Cooperative Extension CT-SJ-03-2. http://coststudies.ucdavis.edu/files/cotton30SJV03.pdf.

Jackson LE, Ramirez I, Morales I, Koike ST. 2002. Minimum tillage practices affect disease and yield of lettuce. Cal Ag 56(1):35-9.

Klocke NL, Currie RS, Aiken RM. 2009. Soil water evaporation and crop residues. T ASABE 52(1):103-10.

Lascano RJ, Baumhardt RL, Hicks SK. 1994. Soil and plant water evaporation from strip-tilled cotton: Measurement and simulation. Agron J 86:987-94.

[MPS] Midwest Plan Service. 2000. Crop residue management with no-till, ridge-till, mulch-till and strip-till. In: Conservation Tillage Systems and Management, MWPS-45, 2nd ed. lowa State University. Ames, IA.

Mitchell J, Hartz T, Pettygrove S, et al. 1999. Organic matter recycling varies with crops grown. Cal Ag 53(4):37-40 Mitchell J, Horwath WR, Shrestha A, et al. 2005. Surface residues in conservation systems in California. In: Map ping Our New Horizons: Soil Science Society of America 69th Annual Meeting, Nov. 6-10, 2005 (Salt Lake City,

UT). Am Soc Agron, Madison, WI. p 64

Mitchell JP, Miyao EM, Klonsky K, DeMoura R. In press. Cover Cropping and Conservation Tillage in California Processing Tomato Production Systems. UC ANR Pub. Oakland, CA.

Mitchell JP, Pettygrove GS, Upadhyaya S, et al. 2009. Classification of Conservation Tillage Practices in California Irrigated Row Crop Systems. UC ANR Pub 8364. Oakland, CA. $8 \mathrm{p}$

Pryor R. 2006. Switching to No-Till Can Save Irrigation Water. Univ Nebraska-Lincoln Ext Pub EC196-3. www. ianrpubs.unl.edu/epublic/live/ec196/build/ec196-3.pdf. Shelton D, Jasa P, Brown L, Hirschi M. 2000. Water erosion In: Conservation Tillage Systems and Management, MWPS45, 2nd ed. MidWest Plan Service, lowa State University. Ames, IA.
Shelton D, Smith J, Jasa P. 2000. Estimating residue cover. In: Conservation Tillage Systems and Management, MWPS 45, 2nd ed. MidWest Plan Service, lowa State University. Ames, IA.

Singh PN, Mitchell JP, Wallender WW. 2011. Parameter optimization for predicting soil water movement under crop residue cover. T ASABE 54(6).

Skidmore EL. 1986. Wind erosion control. Climatic Change 9:209-18.

Unger PW. 2010. Soil and Water Conservation Handbook. Policies, Practices, Conditions, and Terms. Boca Raton, FL: CRC Pr. 248 p.

Unger PW, Parker JJ. 1976. Evaporation reduction from soil with wheat, sorghum and cotton residues. Soil Sci Soc Am J 40:938-42.

Upadhyaya SK, Lancas KP, Santos-Filho AG, Raghuwanshhi NS. 2001. One-pass tillage equipment outstrips conventional tillage method. Cal Ag 55(5):44-7.

[USDA NRCS] US Department of Agriculture Natural Resources Conservation Service. 1996. Soil Survey Laboratory Methods Manual. Soil Survey Investigations Report No. 42, Version 3.0. National Soil Survey Center.

USDA NRCS. 2008. Residue Management, Seasonal. Practice Code 344. http://efotg.sc.egov.usda.gov//references/ public/NM/344stnd2011.pdf.

Valencia JB, May DM, Klonsky KM, De Moura RL. 2002. Sample Costs to Produce Processing Tomatoes Transplanted San Joaquin Valley-South. UC Cooperative Extension TM-VS-02-2. http://coststudies.ucdavis.edu/files/ tomsvstrans02.pdf.

van Donk SJ, Martin DL, Irmak S, et al. 2010. Crop residue cover effects on evaporation, soil water content, and yield of deficit-irrigated corn in west-central Nebraska. T ASABE 53(6):1787-97. 